\title{
Morphology and morphometry of buccopharyngeal cavity and pharyngeal dental apparatus of Chagunius chagunio (Hamilton 1822)
}

\author{
CHAWLA, D. ${ }^{*}$ and TYOR, A. K. \\ Department of Zoology, Kurukshetra University, Kurukshetra-136119, India \\ *E-mail: deepti5june@gmail.com
}

\begin{abstract}
Introduction: Adaptation in morphological and functional aspects of feeding organs is one of the key features in the process of biological evolution. Chagunius chagunio represent remarkable specialization and generalization in their buccopharyngeal cavity. Materials and Methods: The samples ranging from 125-190 mm to study the general shape and size of different subdivisions of buccopharyngeal cavity. Results: Buccopharyngeal cavity measures $32.34 \pm 2.95 \mathrm{~mm}$ in length and $15.3 \pm 2.96 \mathrm{~mm}$ in width. Sickle shaped pharyngeal arch measures $14.52 \pm 1.2 \mathrm{~mm}$ in length and $3.52 \pm 0.74 \mathrm{~mm}$ in width with dental formula $5,32-2,3,5$. Conclusion: The minor carp, Chagunius chagunio has been poorly described in literature. It inhabits fast flowing water, have buccopharyngeal cavity with filter feeding modification as in H. molitrix and H. nobilis with spoon shaped pharyngeal teeth However, It has been described in literature that this fish feed on molluscan larvae.
\end{abstract}

Keywords: Chagunius chagunio, morphology, pharyngeal arch, pharyngeal teeth.

\section{Introduction}

The cyprinid, Chagunius Smith is a polytypic genus of three species, widely distributed in drainage system in south and southeast Asia. Chagunius chagunio (Hamilton, 1822) commonly called as chaguni is endemic to Ganga-Brahamputra river basin characterized by rocky bottom, clear and fast water with little or no vegetation and usually feeds on molluscan larva (TALWAR and JHINGRAN, 1991). As per the IUCN, 2011 red data book (INTERNATIONAL..., 2011), this fish has been kept in the category of "least concerned". As far as taxonomic position of $C$. chagunio is concerned, Hamilton (1822) described this fish as Cyprinus chagunio whereas Shrestha (1978) treated it under the genus Catla. Later, Smith revised it under the genus Chagunius (RAINBOTH, 1986). Literatures pertaining to the morpho-anatomical structures of the buccopharyngeal cavity in freshwater teleosts are fragmentary and many authors (VANAJAKSHI, 1938; KAPOOR, 1958; KHANNA, 1961, 1962; PASHA and KAMAL, 1964a, b, c; SAXENA and BAKHSHI, 1964; LAL, BHATNAGAR and KAILE, 1964; CHITRAY, 1965; SEHGAL, 1966; MOITRA and BHOWMIK, 1967; LAL, 1968; SEHGAL and SALARIA, 1970; MOITRA and SINHA, 1971; SINHA, 1986; SINHA and MOITRA, 1975, 1976, 1978; KAPOOR, SMIT, and VERIGHINA, 1975 ) while studying the alimentary canal, briefly described the morphology and structural organization of the mouth of different fish species. Such study about $C$. chagunio has been documented by Moitra and Sinha, (1971), where the buccopharyngeal cavity and dentition therein has not gained attention of the author. However, morphology of pharyngeal bone has been briefly explained by Rainboth (1986). Since, pharyngeal dental apparatus in fishes has a great evolutionary significance (ZENG and LIU, 2011; TIBBETTS and CARSELDINE, 2003) the aim of the present work was to complement the existing knowledge of bucco-pharyngeal morphology in cyprinids with a study of this system in Chagunius chagunio.

\section{Materials and Methods}

The samples ranging from 125-190 mm were collected from different parts of Haryana during the year 2011-2013. Study specimen were fixed in formalin and brought to the laboratory for measurement. Subdivision of buccal cavity, whereby the anterior pharynx is the region of the gill arches and palatal organ $(\mathrm{PO})$ and the posterior pharynx is the region occupied by the chewing pad (CP) (SIBBING, OSSE and TERLOUW, 1986). The pharyngeal bones (PB) along with teeth and mucous membrane were taken out. The mucous membrane was removed to facilitate the observation of morphology, for this the bone was air dried and then dehydrated in ethanol followed by degreasing in acetone. The definition of the traits on pharyngeal bone (PB) was adopted from Chu (1935) and those on pharyngeal teeth were from Nakajima, Nakajima and Yamazaki (2008) as described in Pasco-Viel, Charles, Chevret et al. (2010); Zeng and Liu (2011). All the measurements were made to the nearest $0.01 \mathrm{~mm}$ with digital calipers to represent the general shape and size. The number of teeth per bone were counted by following Hubbs and Lagler (1958) and Cross (1967) with the aid of dissecting microscope and photographed with Nikon cool pix digital camera. Broken and missing teeth were included in the count.

\section{Results and Discussion}

The adaptations of the buccal cavity and certain other morphological features of mouth are greatly influenced by ecology, ethology of the food and feeding regimes of the species (THOMAS, 1966; SINHA, 1986). The structure of the buccopharyngeal cavity (BC) of Chagunius chagunio 
(Figure 1b) follows a typical pattern of teleost fish. It measures $32.34 \pm 2.95 \mathrm{~mm}$ in length and $15.3 \pm 2.96 \mathrm{~mm}$ in width (Table 1). Mouth gape measures $9.34 \pm 1.09 \mathrm{~mm}$. The maxillae are excluded from the gape and the premaxillae develop articular and ascending processes. The subterminal and slightly protrusible mouth helps the fish, in extracting food from mud as well as enabling it to engulf small prey and other food particles by a quick snap. The PO forms $51 \%$ of buccopharyngeal cavity (BC) by length and $46 \%$ of $\mathrm{BC}$ by width. It has transversely placed mucosal folds on the floor of the cavity which is found to be beset with papillae and the roof of cavity bears six comb plates as a result of which ' $U$ ' shaped notch and transverse shelf are lacking. Comb plate and the gill rackers on the gill arch articulate perpendicularly to form a remarkable sieving structure to facilitate filter feeding (SMITH, 1989) Figure 1b. Similar structures have been reported in purely filter feeders such as Hypophthalmicthys molitrix and H. nobilis (DOOSEY and BART, 2011). In Chagunius, CP is more or less ovoid in shape with mean length $5.6 \pm 0.77 \mathrm{~mm}(17.29 \%$ BC) and

(a)
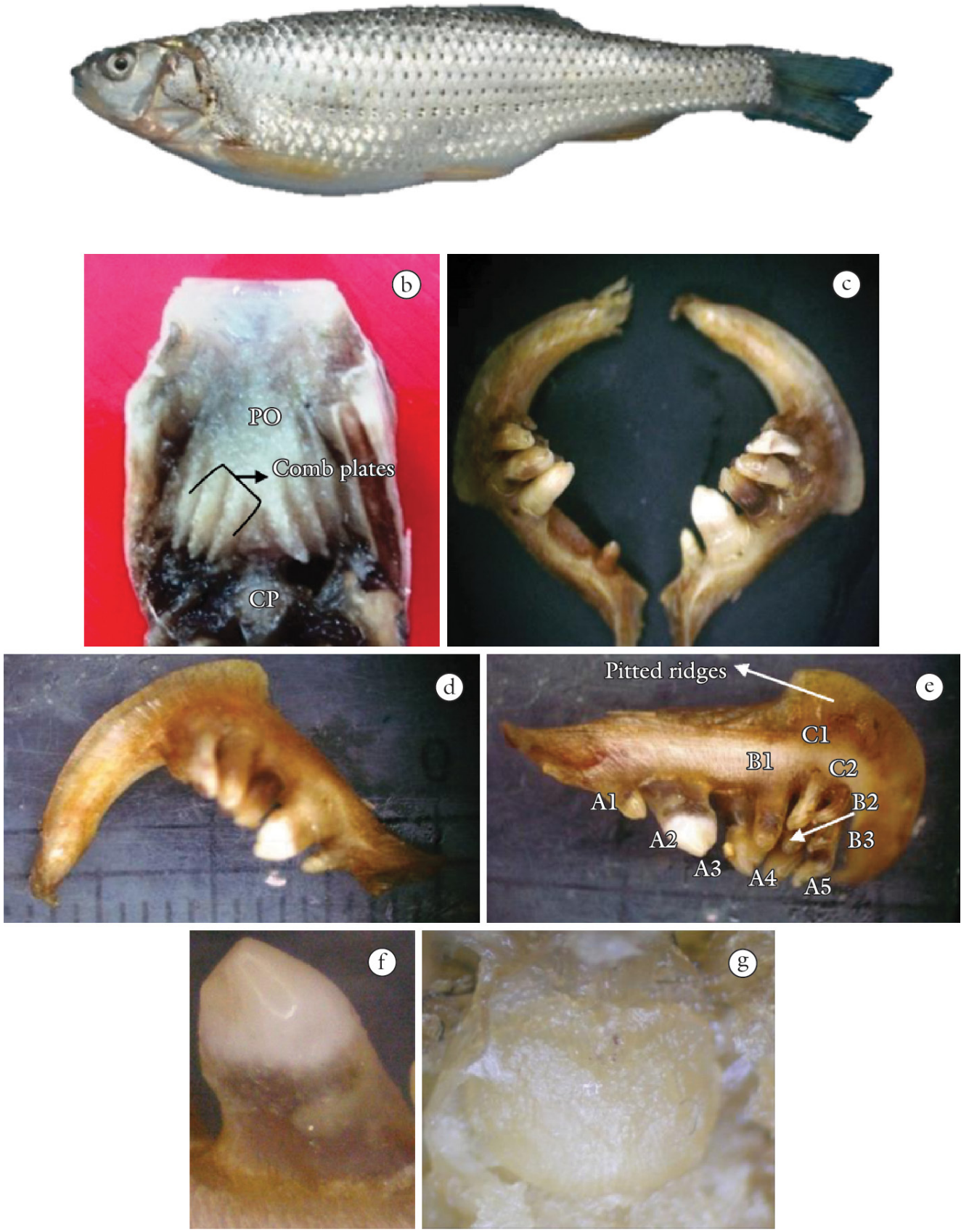

Figure 1. Buccopharyngeal cavity of Chagunius chagunio (a) Fish specimen (b) Buccopharyngeal cavity (c) Pharyngeal jaw arrangement (d) Dorsal side of pharyngeal bone (e) Ventral side of pharyngeal bone (f) Largest Penulimate tooth (g) Pharyngeal pad. 
Table 1. Morphometric measurements of Buccopharyngeal cavity.

\begin{tabular}{|c|c|c|c|}
\hline S. No. & Parameters & Mean \pm SE (in mm) & $\%$ of Buccopharyngeal cavity \\
\hline 1 & $\begin{array}{c}\text { Buccopharyngeal cavity } \\
\text { Length } \\
\text { Width }\end{array}$ & $\begin{array}{r}32.34 \pm 2.95 \\
15.3 \pm 2.96\end{array}$ & ----- \\
\hline 2 & $\begin{array}{c}\text { Palatal organ }(\mathrm{PO}) \\
\text { Length } \\
\text { Width }\end{array}$ & $\begin{array}{r}16.78 \pm 2.57 \\
15.3 \pm 2.96\end{array}$ & $\begin{array}{l}51.27 \pm 3.34 \\
46.46 \pm 6.06\end{array}$ \\
\hline 3 & $\begin{array}{c}\text { Chewing pad (CP) } \\
\text { Length } \\
\text { Width }\end{array}$ & $\begin{array}{r}5.6 \pm 0.77 \\
6.02 \pm 0.65\end{array}$ & $\begin{array}{l}17.29 \pm 1.70 \\
18.66 \pm 1.44\end{array}$ \\
\hline 4 & $\begin{array}{c}\text { Pharyngeal arch (PB) } \\
\text { Length (PL) } \\
\text { Width (PW) }\end{array}$ & $\begin{array}{r}14.52 \pm 1.52 \\
3.57 \pm 0.74\end{array}$ & $\begin{array}{l}45.08 \pm 3.33 \\
11.03 \pm 1.79\end{array}$ \\
\hline 5 & Dentulous region (DL) & $6.94 \pm 1.26$ & $21.43 \pm 2.98$ \\
\hline $\begin{array}{l}6 \\
7 .\end{array}$ & $\begin{array}{c}\text { DL/PL ratio } \\
\text { Height of largest tooth }\end{array}$ & $\begin{array}{c}0.477 \\
3.97 \pm 0.68\end{array}$ & $12 . \overline{38 \pm 2} .01$ \\
\hline
\end{tabular}

mean width averages $6.02 \pm 0.65 \mathrm{~mm}$ which is $18.66 \% \mathrm{BC}$ (Figure 1b, g). It fits loosely into a corresponding fossa in a special masticating process of the basioccipital. Its free surface is rugose and the pharyngeal teeth bite against it. This pad, together with the alternating disposition of the teeth, enabled to shear the food and thus completes an exceedingly efficient masticating apparatus.

There are various reports which refer to or describe the pharyngeal bone and teeth of various cyprinids but none of these studies have been devoted to genus Chagunius. The relationship of the position and form of the teeth in cyprinids has been discussed by Al-Hussaini (1949); Angelescu and Gneri (1949); Blaber, Brewer and Salini (1994), and is considered an important adaptation resulting from evolutionary processes mediated by the nature of the food (VEREGINA, 1990). The fifth branchial arch is reduced to a single strong bone on each side, the 'os pharyngeus inferior' (GOODRICH, 1958), usually referred as the 'pharyngeal jaw'. Eastman and Underhill (1973) and Iliadou and Anderson (1998) highlighted the importance of studying forms and relative dimensions of the pharyngeal arch and shape of the teeth as several species of cyprinids have same dental formula. PB in C. chagunio is sickle shaped and measures $14.52 \pm 1.2 \mathrm{~mm}$ in length and $3.52 \pm 0.74 \mathrm{~mm}$ in width (Figure lc). Each half of the complete arch is about three times its width and its posterior limb which bear teeth is about one and a half times as long as the edentulous anterior half. At the angle between dentulous and edentulous halves, there is a distinct lateral projection just behind the fifth tooth (Figure 1d). Such features have been described by Chu (1935) for the omnivorous species. Ventral surface of the lateral projection is pitted (number of pits variable) and wing-like (Figure le). An edentulous process curves strongly dorsally, making an obtuse posterior angle. This process is compressed and sometimes tapering. It is directed medially, reaching the otic region of the skull where it meets its fellow from the opposite side; thus the two processes form an arch bounding the opening to the oesophagus. The fifth ceratobranchial of the lower tooth plate in species exhibited a pair of robust lateral processes extending ventrally from the middle region of the tooth plate and connecting via cartilage to the lower cleithral region of the pectoral girdle (Figure 1c). They have well developed pharyngeal bone with the rows of teeth steeply inclined towards dorso-mesial orientation of the masticating surface. Similar observation was also documented by Rainboth (1986). Iliadou and Anderson (1998) reported that evolutionary trend favouring the specialization of pharyngeal bone led to an increase in the size, thickness and weight of the bone.

The dissimilarity of teeth bearing area in cyprinids may be related to different movement patterns which thus provide stabilization to bones and help in sustaining crushing function (SIBBING, 1982). On the basis of ratio between dentulous region (DL) and length of pharyngeal bone (PL), Zeng and Liu (2011) classified pharyngeal bone as "small teeth bearing area" $(\mathrm{DL} / \mathrm{PL}<0.5)$ and "large teeth bearing area" (DL/PL $\geq 0.5)$. In C. chagunio $\mathrm{DL} / \mathrm{PL}$ ratio was found to be less than 0.5 . (Table 1 ). Hence, it falls under the category of small teeth bearing area. Chagunius have strong pharyngeal teeth with small terminal hook probably to crush the endoskeleton or even mollusk shell on which they feed.

Pharyngeal tooth formulae provide insight into the evolutionary trends in number of teeth and tooth rows in cyprinids (EASTMAN and UNDERHILL, 1973). According to Vladykov (1934) and Chu (1935), genera with three rows are more common in south eastern Asia whereas one and two rowed genera predominate in Europe and North America. The examined specimen of $C$. chagunio have 10 teeth on each left and right pharyngeal arch arranged in three rows as 5, 3, 2-2, 3, 5 (Figure lc). All teeth have the same general appearance with respect to physical characteristics. They are spoon shaped characterized by concave surface, a pointed tip and a hook as explained by Pasco-Viel et al. (2010). All had a masticating surface, the size of which reaches $2 / 5$ of the total tooth length. Teeth of first row are located upon the jaw Second and third row lies between A3-A5 teeth (Figure le) which are noticeably lower than teeth in main row. The first (anterior most) and second teeth in the main row are somewhat distant from the other teeth. The later are closely arranged forming a triangular 
patch which probably increases the masticating surface area. The hooked and sharp Al tooth is slender and less massive than other teeth. The A2 tooth measures $3.97 \pm 0.68 \mathrm{~mm}$ in height, flatly truncated with smallest or no masticating surface (Figure lf). All the remaining teeth have sharp tip, their crowns are flat and the masticatory surface are narrower and longer. According to Eastman and Underhill (1973), teeth of second row in American cyprinids are usually less functional than of the main row and are usually smaller and less specialized. However, in C. chagunio, all the teeth except $\mathrm{Al}$ and $\mathrm{A} 2$ seem to participate in masticating process. No replacement teeth were observed.

\section{Acknowledgments:}

The authors are thankful to Department of Zoology, Kurukshetra University for providing necessary facilities.

\section{References}

AL-HUSSAINI, AH. On the functional morphology of the alimentary tract of some fish in relation to differences in their feeding habits: anatomy and histology. Quarterly Journal of Microscopical Science, 1949, vol. 90, n. 2, p. 109-139.

ANGELESCU, V. and GNERI, FS. Adaptaciones del aparato digestivo al régimen alimenticio en algunos peces del Río Uruguay y Río de La Plata. Revista del Instituto Nacional de Investigación de las Ciencias Naturales, 1949, vol. 1, n. 6, p. 161-281.

BLABER, SJM., BREWER, DT. and SALINI, JP. Diet and dentition in tropical arid catfishes from Australia. Environmental Biology of Fishes, 1994, vol. 40, n. 2, p. 159-174. http://dx.doi. org $/ 10.1007 /$ BF00002543

CHITRAY, BB. The anatomy and histology of the alimentary canal of Puntius sarana (Ham.) with a note on feeding habits. Ichthyologica, 1965, vol. 4, p. 53-62.

$\mathrm{CHU}, \mathrm{YT}$. Comparative studies on the scales and on the pharyngeals and their teeth in chinese cyprinids with particular reference to taxanomy and evolution. Shanghai: St. John's University, 1935. Biological Bulletin of St. John's University, n. 2.

CROSS, FB. Handbook of fishes of Kansas. Kansas: Museum of Natural History, University of Kansas, 1967. p. 45.

DOOSEY, MH. and BART, LH. Morphological variation of the palatal organ and chewing pad of catostomidae (Teleostei: Cypriniformes). Journal of morphology, 2011, vol. 272, n. 9, p. 10921108. http://dx.doi.org/10.1002/jmor.10966. PMid:21598291.

EASTMAN, JT. and UNDERHIL, JC. Intraspecific variation in the pharyngeal tooth formulae of some cyprinid fishes. Copeia, 1973, n. 1, p. $45-53$.

GOODRICH, ES. Studies on the structure and development of vertebrates. New York: Dover Publications, 1958.

HAMILTON, F. An account of the fishes found in the river Ganges and its branches. Edinburg: Printed for Archibald Constable and Company, 1822. vol. 1, i-vii + 1-405, Pls. 1-39.

HUBBS, CL. and LAGLER, KF. Fishes of the Great Lakes Region. Revised edition. Bloomfield Hills: Cranbrook Institute of Science, 1958. vol. 26.

ILIADOU, K. and ANDERSON, MJ. Morphometric comparative analysis of pharyngeal teeth of the genus Scardinius (Pisces: Cyprinidae) in Greece. Journal of Natural History, 1998, vol. 32, n. 6, p. 923-941. http://dx.doi.org/10.1080/00222939800770471
INTERNATIONAL UNION FOR CONSERVATION OF NATURE AND NATURAL RESOURCES - IUCN. IUCN red list of threatened species. Cambridge, 2011.

KAPOOR, BG. The anatomy and histology of the alimentary tract of a plankton feeder, Gadusia chapra (Ham.). Annali del Museo Civico di Storia Naturale, 1958, vol. 70, p. 8-32.

KAPOOR, BG., SMIT, H. and VERIGHINA, IA. The alimentary canal and digestion in Teleosts. Advances in Marine Biology, 1975, vol. 13, p. 109-239.

KHANNA, SS. Alimentary canal in some teleostean fishes. Journal of the Zoological Society of India, 1961, vol. 13, p. 206-219.

KHANNA, SS. A study of bucco-pharyngeal region in some fishes. Indian Journal of Zootomy, 1962, vol. 3, p. 21-48.

LAL, MB. Studies on the anatomy and histology of the alimentary canal of a carp, Tor putitora Hamilton. Proceedings of the National Academy of Sciences: India, 1968, vol. 38, p. 127-136.

LAL, MB., BHATNAGAR, AN. and KAILE, RK. Studies on the morphology and histology of the digestive tract and associated structures of Chagunius chagunio Hamilton. Proceedings of the National Academy of Sciences: India, 1964, vol. 34, p. 160-172.

MOITRA, SK. and BHOWMIK, ML. Functional histology of the alimentary canal of the young Catla catla Ham. An omnivorous surface-feeding fish of Indian fresh-waters. Věstník Československé společnosti zoologické, 1967, vol. 10, p. 940-949.

MOITRA, SK. and SINHA, GM. Studies on the morphohistology of the alimentary canal of a carp, Chagunius chagunio Hamilton with reference to the nature of taste buds and mucous cells. Journal of the Inland Fisheries Society of India, 1971, vol. 3, p. 44-56.

NAKAJIMA, T., NAKAJIMA, M. and YAMAZAKI, T. Evidence for fish cultivation during the Yayoi period in western Japan. International Journal of Osteoarchaeology, 2008, vol. 20, n. 2, p. 127-134.

PASCO-VIEL, E., CHARLES, C., CHEVRET, P., SEMON, M., TAFFOREAU, P., VIRIOT, L. and LUDET, V. Evolutionary trends of the pharyngeal dentition in Cypriniformes (Actinoptergii: Ostariophysi). PLoS ONE, 2010, vol. 5, n. 6, p. 11293. http:// dx.doi.org/10.1371/journal.pone.0011293. PMid:20585584. PMCid:PMC2892034.

PASHA, A. and KAMAL, SM. The anatomy and histology of the alimentary canal of an omnivorous fish Mystus Macrones gulio Ham. Proceedings of the Indian Academy of Sciences, 1964a, vol. 59, p. 211-221.

PASHA, A. and KAMAL, SM. The anatomy and histology of the alimentary canal of a herbivorous fish Tilapia mossambica Peters. Proceedings of the Indian Academy of Sciences, 1964b, vol. 59, p. 340-349.

PASHA, A. and KAMAL, SM. The anatomy and histology of the alimentary canal of a carnivorous fish Megalops cyprinoides Brouss. Proceedings of the Indian Academy of Sciences, 1964c, vol. 60, p. 107-115.

RAINBOTH, WJ. Fishes of the Asian cyprinid genus Chagunius. Ann Arbor: University of Michigan Museum of Zoology, 1986. Occasional Papers, 712.

SAXENA, DB. and BAKSHI, PL. Functional anatomy of the alimentary canal of a torrential stream fish Botia birdi (Choudhari). Kashmir Science, 1964, vol. 1, p. 76-86.

SEHGAL, P. Anatomy and histology of the alimentary canal of Labeo calbasu Hamilton. Research Bulletin N.S. of the Panjab University, 1966, vol. 17, p. 257-266. 
SEHGAL, P. and SALARIA, J. Functional anatomy and histology of the digestive organs of Cirrbinus mrigala Cuvier and Val. Proceedings of the National Academy of Sciences: India, 1970, vol. 40 , p. 212-222.

SHRESTHA, J. Fish fauna of Nepal. Journel of Natural History Museum, 1978, vol. 5, n. 14, p. 33-43.

SIBBING, FA. Pharyngeal mastication and food transport in the carp (Cyprinus carpio L.): a cineradiographic and electromyographic study. Journal of Morphology, 1982, vol. 172, n. 2, p. 223-258. http://dx.doi.org/10.1002/jmor.1051720208.

SIBBING, FA., OSSE, JGM. and TERLOUW, A. Food handling in the carp (Cyprinus carpio): its movement patterns, mechanism and limitations. Journal of Zoology, 1986, vol. 210, n. 2, p. 161-203.

SINHA, GM. and MOITRA, SK. Functional morphohistology of the alimentary canal of an Indian fresh water major carp, Labeo robita Ham. during its different life history stages. Anatomischer Anzeiger, 1975, vol. 138, n. 3, p. 222-239. PMid:1217739.

SINHA, GM. and MOITRA, SK. Studies on the morphohistology of the alimentary canal of freshwater fishes of India. I. The alimentary canal of young Cirrbinus reba Ham. with a comparison with that of the adult in relation to food. Věstník Československé společnosti zoologické, 1976, vol. 40, p. 221-231.

SINHA, GM. and MOITRA, SK. Studies on the comparative histology of the taste buds in the alimentary tract of a herbivorous fish, Labeo calbasu Ham. and a carnivorous fish, Clarius batrachus Linn. in relation to food and feeding habits. Zoologische Beitröge, 1978, vol. 24, p. 43-57.

SINHA, M. Functional morphology, anatomy and histology of the digestive organ of the catfish, Plotosus canius (Ham.). Proceedings: Animal Sciences, 1986, vol. 95, n. 1, p. 23-44. http://dx.doi. org/10.1007/BF03179355.

SMITH, DW. The feeding selectivity of silver carp, Hypophthalmicthys molitrix Val. Journal of Fish Biology, 1989, vol. 34, n. 6, p. 819-828. http://dx.doi.org/10.1111/j.1095-8649.1989.tb03366.x.
TALWAR, PK. and JHINGRAN, AG. Inland fishes of India and adjacent countries. New Delhi: Oxford \& IBH Publishing Company, 1991.

THOMAS, JD. On the biology of the catfish Clarias senegalensis, in a man made lake in the Ghanaian savanna, with particular reference to its feeding habits. Journal of Zoology, 1966, vol. 148, n. 4, p. 476-514.

TIBBETTS, IR. and CARSELDINE, L. Anatomy of a hemiramphid pharyngeal mill with reference to Arrhamphus sclerolepis kreffti (Steindachner) (Teleostei: Hemiramphidae). Journal of morphology, 2003, vol. 255, n. 2, p. 228-243. http://dx.doi.org/10.1002/ jmor.10057. PMid:12474268.

VANAJAKSHI, TP. Histology of the digestive tract of Saccobranchus fossilis and Macrones vittatus. Proceedings of the Indian Academy of Sciences, 1938, vol. 7, n. 2, p. 61-79.

VEREGINA, IA. Basic adaptations of the digestive system in bony fishes as a function of diet. Journal of Ichthyology, 1990, vol. 30, n. 6, p. 897-907.

VLADYKOV, VD. Geographic variation in the number of rows of pharyngeal teeth in cyprinid genera. Copeia, 1934, vol. 1934. n. 3, p. 134-136. http://dx.doi.org/10.2307/1436758.

ZENG, Y and LIU, H. The evolution of pharyngeal bones and teeth in Gobioninae fishes (Teleostei: Cyprinidae) analysed with phylogenetic comparative methods. Hydrobiologia, 2011, vol. 664, n. 1, p. 183-197. http://dx.doi.org/10.1007/s10750-0100598-8. 